\title{
Efektivitas Salep Ekstrak Etil Asetat Daun Gliricidia Sepium (Jacq.) Walp. terhadap Penyembuhan Luka Sayat pada Tikus Putih Jantan
}

\section{Effectivity of Gliricidia Sepium (Jacq.) Walp. Folium Ethyl Acetate Extract Ointment on Wound Healing in Male White Rats}

\author{
I Gusti Agung Ayu Kusuma Wardani ${ }^{\mathbf{1}}$, Ni Nyoman Wahyu Udayani ${ }^{2}$, I Gusti Ayu Arya Ditha Suari ${ }^{1}$ \\ ${ }_{1}^{1}$ Program Studi Diploma Tiga Farmasi, Fakultas Farmasi, Universitas Mahasaraswati Denpasar, Kota Denpasar \\ 2Program Studi Sarjana Farmasi, Fakultas Farmasi, Universitas Mahasaraswati Denpasar, Kota Denpasar
}

\begin{abstract}
Abstrak: Luka adalah rusak atau hilangnya jaringan tubuh yang terjadi karena adanya suatu faktor yang mengganggu sistem perlindungan tubuh. Di Pulau Bali salah satu tanaman yang digunakan secara tradisional untuk mengobati luka, khususnya luka sayat adalah daun gamal (Gliricidia Sepium (Jacq.) Walp). Penelitian ini bertujuan untuk mengetahui efektivitas salep ekstrak etil asetat daun gamal terhadap penyembuhan luka sayat pada tikus putih jantan. Metode yang digunakan yaitu randomized control group pretest posttest design dengan menggunakan 25 ekor tikus yang dibagi menjadi 5 kelompok perlakuan. Sebelum dilukai, semua tikus dianastesi menggunakan kombinasi ketamine dan zylasin dengan perbandingan 25:8. Luka sayat dibuat di punggung tikus dengan kedalaman $2 \mathrm{~mm}$ menggunakan cutter. Perawatan luka dilakukan dengan mengoleskan salep ekstrak dan betadine ke bagian tubuh yang terluka sebanyak 2 kali sehari. Hasil uji LSD menunjukkan adanya perbedaan bermakna waktu penyembuhan luka sayat antara kelompok P1 dengan kelompok P2, P3, P4, dan P5 dengan nilai signifikan 0,$002 ; 0,044 ; 0,004 ; 0,002$ secara berturut-turut $(p<0,05)$. Pada kelompok $P 2$ dengan kelompok P3, P4 dan P5 tidak memiliki perbedaan bermakna dengan nilai signifikan 0,168 ; 0,$724 ; 1,000$ secara berturut-turut $(p>0,05)$. Berdasarkan penelitian yang telah dilakukan dapat disimpulkan bahwa ekstrak etil asetat daun gamal (Gliricidia sepium (Jacq.) Walp) dengan konsentrasi $30 \%$ sudah mampu mempercepat waktu penyembuhan luka sayat pada tikus putih jantan.
\end{abstract}

Kata Kunci: daun gamal, luka sayat, salep.

\begin{abstract}
Wounds are damage or loss of body tissue that occurs due to a factor that interferes with the body's protection system. In Bali island, one of the plants used traditionally to treat wounds, especially incision wound, is Gamal leave (Gliricidia Sepium (Jacq.) Walp). This study aims to determine the effectiveness of extract ointment from gamal leaves on wound healing. The method used was a randomized control group pretest posttest design using 25 male white rats which were divided into 5 treatment groups. Prior to injury, all rats were anesthetized using a combination of ketamine and zylasin in a ratio of 25:8. An incision was made on the rat's back with a depth of $2 \mathrm{~mm}$ using a cutter. Wound care is done by applying ointment and betadine to the injured body part 2 times a day. The results of the LSD test showed that there was a significant difference in wound healing time in rats between $\mathrm{P} 1$ with $\mathrm{P} 2, \mathrm{P} 3, \mathrm{P} 4$, and $\mathrm{P} 5$ with a significant value of $0.002 ; 0.044 ; 0.004 ; 0.002$ consecutively $(p<0.05)$. In $P 2$ with treatment groups $P 3, P 4$ and $P 5$ there was no significant difference with a significant value of $0.168 ; 0.724 ; 1,000$ consecutively $(p>0.05)$. Based on the research that has been done, it can be concluded that the ethyl acetate extract of gamal leave with a concentration of $30 \%$ was able to accelerate the healing time of cuts in male white rats.

Keywords: gamal leave, ointment, wound incision.
\end{abstract}

\section{PENDAHULUAN}

Luka merupakan hilang atau rusaknya jaringan tubuh yang terjadi karena adanya suatu faktor yang mengganggu sistem perlindungan tubuh. Luka insisi atau luka sayat merupakan salah satu jenis luka dengan manifestasi klinis terdapat robekan linear pada kulit dan jaringan di bawahnya (Pusponegoro, 2005).

Berdasarkan hasil Riskesdas prevalensi luka di Indonesia tiap tahunnya

•email korespondensi: kusumawardani@unmas.ac.id 
mengalami peningkatan yaitu pada tahun 2007 sebesar $25,9 \%$ menjadi $47,7 \%$ pada tahun 2013 . Tiga urutan tertinggi untuk luka yang dialami penduduk adalah luka lecet/memar $(70,9 \%)$, terkilir $(27,5)$ dan luka robek (23,2\%) (Kemenkes, 2013)

Penanganan luka yang tepat, memegang peranan penting untuk mencegah infeksi. Pemberian antiseptik povidone iodine berguna untuk membunuh dan menghambat pertumbuhan bakteri. Namun saat ini, povidone iodine sering diperdebatkan oleh paramedis karena dapat menyebabkan kerusakan sel dan jaringan (Miladiyah and Prabowo, 2012). Adanya pertimbangan penggunaan zat kimia sintetik yang mahal, terlebih mempunyai efek samping membahayakan tubuh, menyebabkan obat dari tanaman menarik perhatian masyarakat sebagai alternatif penyembuhan yang lebih berpotensi, murah, memiliki efek samping yang lebih kecil, dan tersedia dalam jumlah besar (Prasetyo, Wientarsih and Priosoeryanto, 2010)

Salah satu tanaman yang telah digunakan secara tradisional dalam penyembuhan luka sayat adalah daun gamal. Dari hasil penelitian yang telah dilakukan diketahui daun gamal mengandung golongan senyawa metabolit sekunder yaitu saponin, terpenoid, steroid, tannin, alkaloid serta flavonoid yang memiliki fungsi untuk mempercepat proses penyembuhan luka (Ulfa et al., 2016) (Yogi, 2018). Namun belum ada penelitian lebih lanjut tentang efektivitas daun gamal dalam menyembuhkan luka, khususnya luka insisi.

Berdasarkan latar belakang tersebut maka perlu dilakukan penelitian untuk mengetahui efektivitas salep ekstrak etil asetat daun gamal (Gliricidia sepium (Jacq.) Walp) terhadap penyembuhan luka sayat pada tikus putih (Rattus norvegicus L.) jantan.

\section{METODE PENELITIAN}

Alat. Alat yang digunakan dalam penelitian ini diantaranya: timbangan analitik Digital Scale (Ohaus), blender (Philip), Rotary Evaporator, kertas saring, oven, corong Buchner (vakum), sonde, jangka sorong, spuit injeksi, pisau, gunting, dan cutter.
Bahan. Bahan yang digunakan dalam penelitian ini adalah daun gamal (Gliricidia Sepium (Jacq.) Walp) diperoleh di Desa Getakan, Kabupaten Klungkung, Bali yang telah dideterminasi di LIPI. Daun yang dipetik adalah daun yang masih segar dan berwarna hijau. Bahan kimia yang digunakan dalam penelitian ini adalah etil asetat, betadin, adeps lanae, vaselin album, veet, ketamine dan xylazin. Sampel dalam penelitian ini adalah tikus putih jantan yang diperoleh di Pengembangan dan Pemeliharaan Hewan Jl. Pulau Moyo No.15 Perum Telkom No. $11 \mathrm{~A}$ Denpasar yang memenuhi kriteria inklusi dan eksklusi. Adapun kriteria inklusi dalam penelitian ini yaitu: tikus putih jantan dewasa, umur 12-15 minggu, berat badan 180-200 g. Kriteria eksklusi dalam penelitian ini adalah tikus yang sakit atau mati selama penelitian. Pada penelitian ini digunakan 25 tikus yang dibagi menjadi 5 kelompok.

\section{Prosedur Penelitian.}

Rancangan penelitian yang digunakan adalah Randomized Control Group Pretest Postest design. Pada penelitian ini, hewan coba akan dibagi secara acak ke dalam 5 kelompok. Kelompok kontrol negatif (P1), kelompok kontrol positif menggunakan Betadine (P2), kelompok ekstrak 30\% (P3), kelompok ekstrak 40\% (P4), kelompok ekstrak 50\% (P5). Sebelum perlakuan, tikus diadaptasi selama 7 hari Adapun tahapan-tahaan penelitian diantaranya:

\section{Pembuatan ekstrak simplisia}

Ekstrak etil asetat daun gamal dibuat dengan menggunakan perbandingan 1:7 (1 g serbuk daun gamal dalam $7 \mathrm{ml}$ pelarut etil asetat). Serbuk simplisia daun gamal ditimbang sebanyak $200 \mathrm{~g}$ menggunakan timbangan analitik kemudian dipindahkan ke dalam toples dan ditambahkan pelarut etil asetat sebanyak $1.400 \mathrm{ml}$, dibiarkan 5 hari terlindung dari cahaya sambil sering diaduk. Kemudian disaring, diperas dan ampasnya dicuci dengan etil asetat secukupnya. Maserat dibiarkan di tempat sejuk dan terlindung dari cahaya selama 2 hari sambil sering diaduk kemudian disaring. Maserat yang diperoleh kemudian diuapkan dalam lemari asam selama beberapa hari hingga diperoleh ekstrak kental. 


\section{Teknik pembuatan luka}

Sebelum pembuatan luka, tikus putih dianastesi terlebih dahulu menggunakan ketamine dan xylazin dengan perbandingan 25:8 (Yudaniayanti, 2005). Luka sayat dibuat di punggung mecit menggunakan cutter dengan panjang $2 \mathrm{~cm}$ dan kedalaman $2 \mathrm{~mm}$.

\section{Prosedur pembuatan salep}

Disiapkan alat dan bahan, ditimbang semua bahan sesuai perhitungan, mortar dipanaskan. Vaselin album dan adeps lanae diaduk di dalam mortar panas hingga terbentuk basis salep. Ditambahkan ekstrak etil asetat daun gamal ke dalam mortar sesuai konsentrasi yang ditetapkan dan diaduk hingga homogen. Formulasi salep dapat dilihat pada Tabel 1.

Tabel 1. Formula salep ekstrak etil asetat daun gamal (Gliricidia sepium (Jacq.) Walp)

\begin{tabular}{ccc}
\hline Formula & Bahan & Jumlah (\%) \\
\hline Formula 1 (basis salep) & Adeps lanae & 15 \\
Formula 2 & Vaselin album & 85 \\
Formula 3 & Ekstrak etil asetat daun gamal & 30 \\
(ekstrak etil asetat daun gamal 30\%) & Adeps lanae & 10,5 \\
Formula 4 & Vaselin album & 59,5 \\
(ekstrak etil asetat daun gamal 40\%) & Ekstrak etil asetat daun gamal & 40 \\
(ekstrak etil asetat daun gamal 50\%) & Adeps lanae & 9 \\
& Vaselin album & 51 \\
& Ekstrak etil asetat daun gamal & 50 \\
& Adeps lanae & 7,5 \\
\hline
\end{tabular}

\section{Prosedur perawatan luka sayat}

Perawatan luka dilakukan dengan pemberian salep ekstrak etil asetat daun gamal dua kali sehari yaitu pagi hari jam 08.00 dan malam hari jam 20.00. Perawatan luka dievaluasi sampai terlihat tandatanda penyembuhan luka yang ditandai dengan tidak adanya kemerahan, inflamasi dan menutupnya luka.

\section{Pengamatan luka sayat}

Pengamatan luka dilakukan setiap hari sampai luka sembuh. Pengamatan yang dilakukan yaitu terpenuhinya indikator seperti tidak adanya kemerahan, bengkak dan luka menutup. Bila indikator tersebut telah terpenuhi maka luka dapat dikatakan sembuh.

Analisis Data. Data yang diperoleh dianalisis dengan menggunakan program statistika metode SPSS versi 23. Data dianalisis menggunakan uji normalitas Shapiro-Wilk untuk melihat sebaran data normal atau tidak. Uji homogenitas varians bertujuan untuk melihat apakah data yang diuji homogen.
Selanjutnya dilakukan uji One Way ANOVA untuk mengetahui apakah terdapat perbedaan bermakna antara kelompok yang diuji. Uji Post Hoc LSD bertujuan untuk melihat kelompok yang berbeda bermakna.

\section{HASIL DAN PEMBAHASAN}

Berdasarkan hasil pengamatan menunjukkan rata-rata sampel mengalami reaksi hiperemis (kemerahan) mulai dari 24-36 jam setelah perlakuan. Hiperemis merupakan bentuk perubahan vaskular yang merupakan salah satu komponen utama pada respon inflamasi akut. Respon ini berlangsung selama 1-2 hari pertama dan dapat menetap hingga 2 minggu pasca perlukaan (Li, Juan and Kirsner, 2007). Perubahan vaskular ini ditandai dengan adanya warna kemerahan (rubor) pada kulit yang disertai dengan nyeri (dolor), rasa hangat (kalor), dan pembengkakan (tumor). Saat terjadi luka, tubuh akan merespon dengan vasokonstriksi pembuluh darah untuk menghentikan perdarahan. 
Keadaan ini diikuti dengan pelepasan mediator inflamasi dan sel mast yang menyebabkan vasodilatasi. Reaksi vasodilatasi mengakibatkan peningkatan aliran darah dan penyumbatan lokal sehingga menimbulkan warna kemerahan dan rasa hangat pada daerah luka (Sjamsuhidajat and Jong, 2005). Vasodilatasi arteriol dan aliran darah yang bertambah meningkatkan pergerakan cairan dari kapiler dan tekanan hidrostatik intravaskular. Hilangnya cairan kaya protein ke dalam ruang perivaskular menurunkan tekanan osmotik intravaskular dan meningkatkan tekanan osmotik cairan interstisial. Keadaan ini mengakibatkan mengalirnya air dan ion ke dalam jaringan ekstravaskular yang dapat diamati dengan terlihatnya edema pada daerah luka (Campbell, Reece and Lisa, 2010)

Waktu penyembuhan luka pada masingmasing kelompok dapat dilihat pada Gambar 1. Kelompok P1 memiliki rata-rata waktu penyembuhan luka sayat selama 7,8 hari, kelompok P2 selama 5,8 hari, kelompok P3 selama 6,6 hari, kelompok perlakuan 4 selama 6,0 hari, dan kelompok P5 selama 5,8 hari. Kelompok perlakuan yang diberi salep ekstrak etil daun gamal memiliki waktu penyembuhan yang lebih cepat dibandingkan kelompok kontrol negatif, hal ini disebabkan pada ekstrak daun gamal terdapat kandungan senyawa metabolit sekunder yang efektif dalam menyembuhkan luka sayat.

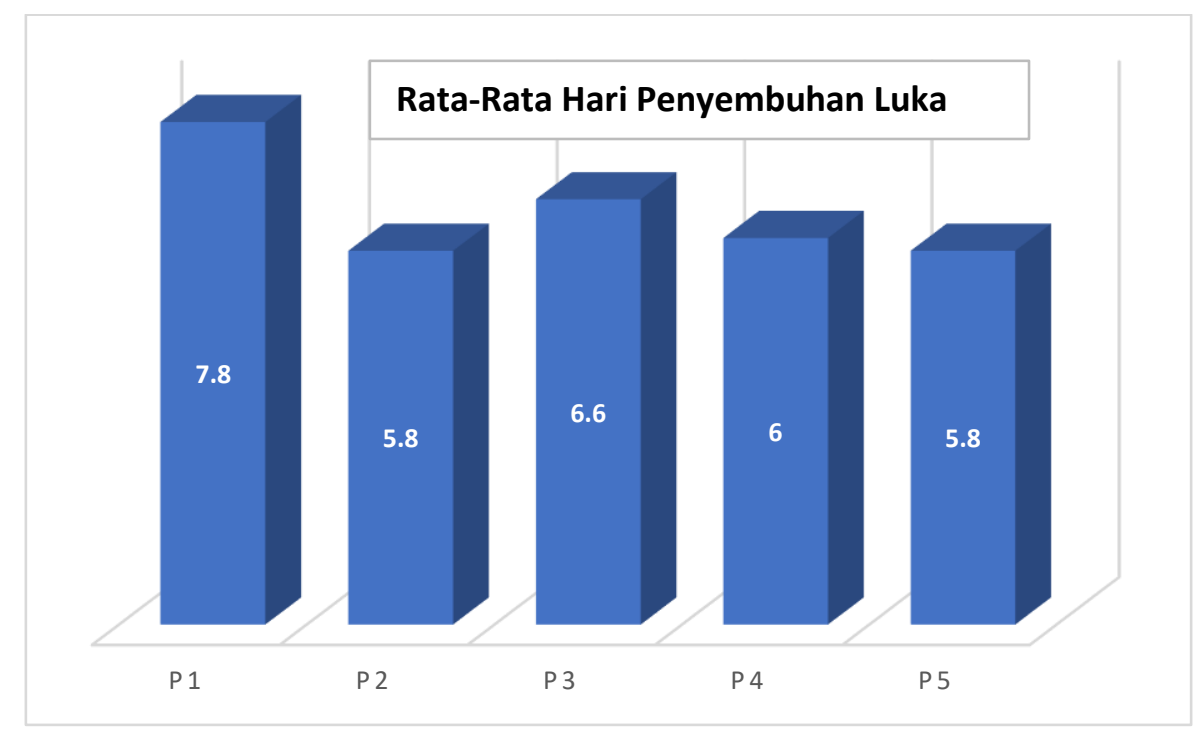

Gambar 1. Rata-rata penyembuhan luka sayat pada tikus (dalam satuan hari)

Berdasarkan penelitian yang telah dilakukan diketahui bahwa daun gamal mengandung senyawa alkaloid, fenol, tannin, saponin, terpenoid, steroid, flavonoid (Ulfa et al., 2016) (Yogi, 2018). Dari banyaknya kandungan senyawa metabolit sekunder yang terdapat dalam daun gamal, diketahui bahwa senyawa golongan flavonoid, tannin, saponin, dan alkaloid dapat membantu dalam proses penyembuhan luka sayat.

Dalam bidang farmasi, senyawa tannin digunakan sebagai adstringen, antioksidan serta antibakteri (Aryantini, 2021). Kemampuan tannin sebagai adstringen dapat menyebabkan penciutan pori-pori kulit, memperkeras kulit, menghentikan eksudat dan pendarahan yang ringan, sehingga keropeng lebih cepat terlepas dan luka tertutup (Laguliga, Erviani and Soekendarsi, 2021). Selain itu, tannin bermanfaat sebagai antibakteri dengan mengerutkan dinding sel atau membran sel bakteri sehingga menghambat permeabilitas bakteri untuk berkembang (Ajizah, 2004). Antibakteri dibutuhkan pada proses penyembuhan luka terutama pada fase dekstrutif yang berlangsung bersamaan dengan fase inflamasi dimana terjadi pembersihan terhadap jaringan mati atau yang mengalami devitalisasi (Jayalandri et al., 2016). Adanya tannin diduga akan mempercepat penutupan luka karena tidak adanya mikroorganisme pada luka.

Aktivitas alkaloid dapat meningkatkan proliferasi seluler pada lokasi luka yang disebabkan 
oleh sintesis kolagen yang mengalami pengendapan. Alkaloid berkontribusi terhadap proses penyembuhan luka dengan cara pembentukan jaringan granular dan epitelisasi, regenerasi sel dermal dan epidermal secara dini, serta memiliki efek positif terhadap proliferasi seluler. Selain itu, senyawa alkaloid dapat menginisiasi fibroblast menuju daerah luka. Fibroblas merupakan salah satu komponen penting dalam penyembuhan luka, dengan kehadiran fibroblas yang semakin banyak maka proses penyembuhan luka akan menjadi lebih cepat (Diegelmann and Evans, 2004).

Saponin merupakan golongan triterpenoid yang diidentifikasi memiliki manfaat yaitu mengurangi gejala inflamasi (menghambat eritema dan edema), antimikroba, mempengaruhi kolagen, serta memperbaiki dan menguatkan sel-sel kulit. Dalam penyembuhan luka saponin juga bekerja dengan meningkatkan epitelisasi jaringan, menstimulasi pembentukan kolagen tipe 1 yang berperan penting dalam proses penutupan luka, mempercepat migrasi sel epitel, sebagai antimikroba dan antioksidan (Miladiyah and Prabowo, 2012).

Flavonoid berperan sebagai antiinflamasi dengan melancarkan peredaran darah ke seluruh tubuh dan mencegah terjadinya penyumbatan pada pembuluh darah. Flavonoid juga memiliki aktivitas antioksidan dan membantu mengurangi rasa sakit jika terjadi pendarahan atau inflamasi. Dalam proses penyembuhan luka, flavonoid bekerja dengan meningkatkan proliferasi sel epitel dan kolagen sehingga proses penutupan luka lebih cepat (Muralidhar et al., 2013). Flavonoid juga bekerja dengan mencegah dan memperlambat kematian sel, menginhibisi proses lipid peroksidasi dan menghilangkan radikal bebas, serta meningkatan vaskularisasi pada daerah luka. Inhibisi lipid peroksidase dipercaya dapat meningkatkan serabut kolagen dan vaskularisasi, serta mencegah kerusakan sel, dan membantu sintesis DNA (Miladiyah and Prabowo, 2012).

Tabel 2. Hasil Uji LSD Lama Waktu Penyembuhan Luka

\begin{tabular}{|c|c|c|c|}
\hline \multicolumn{2}{|c|}{ Kelompok perbandingan } & \multirow{2}{*}{$\begin{array}{c}\text { Nilai } p \\
(<0,05) \\
0,002\end{array}$} & \multirow{2}{*}{$\begin{array}{c}\text { Keterangan } \\
\text { ada perbedaan bermakna }\end{array}$} \\
\hline Perlakuan 1 & Perlakuan 2 & & \\
\hline & perlakuan 3 & 0,044 & ada perbedaan bermakna \\
\hline & perlakuan 4 & 0,004 & ada perbedaan bermakna \\
\hline & perlakuan 5 & 0,002 & ada perbedaan bermakna \\
\hline \multirow[t]{3}{*}{ Perlakuan 2} & perlakuan 3 & 0,168 & tidak ada perbedaan bermakna \\
\hline & perlakuan 4 & 0,724 & tidak ada perbedaan bermakna \\
\hline & perlakuan 5 & 1,000 & tidak ada perbedaan bermakna \\
\hline \multirow[t]{2}{*}{ Perlakuan 3} & perlakuan 4 & 0,296 & tidak ada perbedaan bermakna \\
\hline & perlakuan 5 & 0,168 & tidak ada perbedaan bermakna \\
\hline Perlakuan 4 & perlakuan 5 & 0,724 & tidak ada perbedaan bermakna \\
\hline
\end{tabular}

Rata-rata waktu penyembuhan luka sayat diuji normalitasnya dengan menggunakan uji Shapiro-Wilk. Hasil analisis menunjukkan bahwa data terdistribusi normal dengan nilai $p>0,05$. Dari hasil uji homogenitas varians dengan menggunakan Levenne test menunjukkan bahwa data homogen dengan nilai $p=0,666(p>0,05)$.

Dengan diterimanya uji normalitas dan uji homogenitas varians maka selanjutnya data diuji dengan menggunakan uji One Way ANOVA. Dari uji One Way ANOVA diperoleh nilai $p=0,008(p<0,05)$, hal ini menunjukkan bahwa setidaknya terdapat dua kelompok yang memiliki perbedaan bermakna pada rata-rata waktu penyembuhan luka.

Untuk mengetahui kelompok mana yang memiliki perbedaan bermakna maka selanjutnya dilakukan uji post hoc yaitu LSD. Hasil uji LSD (Tabel 2) menunjukkan adanya perbedaan bermakna waktu penyembuhan luka sayat pada tikus antara kelompok P1 dengan kelompok P2, P3, P4, dan P5 dengan nilai signifikan 0,$002 ; 0,044 ; 0,004 ; 0,002$ secara berturut-turut $(\mathrm{p}<0,05)$. Pada kelompok perlakuan 2 dengan kelompok perlakuan 3, 4 dan 5 tidak memiliki perbedaan bermakna dengan nilai 
signifikan 0,$168 ; 0,724 ; 1,000$ secara berturut-turut ( $p>0,05)$. Hal ini menunjukkan bahwa kelompok perlakuan yang diberi salep ekstrak etil asetat daun gamal dan kelompok kontrol positif memiliki efektivitas yang signifikan terhadap waktu penyembuhan luka sayat pada tikus putih jantan

\section{SIMPULAN}

Berdasarkan penelitian yang telah dilakukan dapat disimpulkan bahwa ekstrak etil asetat daun gamal (Gliricidia sepium (Jacq.) Walp) dengan konsentrasi $30 \%$ sudah mampu mempercepat waktu penyembuhan luka sayat pada tikus putih jantan.

\section{DAFTAR PUSTAKA}

Ajizah, A. (2004) 'Sensitivitas Salmonella Typhimurium Terhadap Ekstrak Daun Psidium Guajava L. Bioscientiae', Bioscientiae, 1(1), pp. 8-31.

Aryantini, D. (2021) 'Aktivitas Antioksidan dan Kandungan Tanin Total Ekstrak Etanol Daun Kupu-Kupu (Bauhinia purpurea L.)', Jurnal Farmagazine, 8(1), pp. 54-60. doi: http://dx.doi.org/10.47653/farm.v8i1.537.

Campbell, N. A., Reece, J. B. and Lisa, A. U. (2010) Biologi Edisi Kedelapan jilid 3. Jakarta: Erlangga.

Diegelmann, R. F. and Evans, M. C. (2004) 'Wound healing: An overview of acute, fibrotic, and delayed healing', Bioscience, 9(1), pp. 283-9.

Jayalandri, L. G. et al. (2016) 'Uji Efektivitas ekstrak melkati (Jasminum Sambaci) pada Penyembuhan Luka Insisi Kelinci (Oryctolagus cuniculus)', Journale-Biomedik, 4(1).

Kemenkes, R. (2013) Riset Kesehatan Dasar "Riskesdas 2013".

Laguliga, J. A., Erviani, A. E. and Soekendarsi, E. (2021) 'Uji Potensi Getah Jarak Pagar (Jatropha curcas Linn.) terhadap Kecepatan Penyembuhan Luka Bakar pada Kulit Tikus (Rattus novergicus)', Jurnal Biologi Makassar, pp. 74-83.
Li, J., Juan, C. and Kirsner, R. (2007) 'Pathophysiology of acute wound healing', Clinics in Dermatology, 25, pp. 9-18.

Miladiyah, I. and Prabowo, B. R. (2012) 'Ethanolic Extract of Anredera cordifolia (Ten.) Steenis Leaves Improved Wound Healing in Guinea Pigs', Univ Med., 31(1), pp. 4-11.

Muralidhar, A. et al. (2013) 'Wound healing activity of flavonoid fraction isolated from the stem bark of Butea monosperma (Lam) in albino Wistar rats', European Journal of Experimental Biology, 3(6), pp. 1-6.

Prasetyo, B., Wientarsih, I. and Priosoeryanto, B. (2010) 'Aktivitas Sediaan Gel Ekstrak Batang Pohon Pisang Ambon dalam Proses Penyembuhan Luka pada Mencit', Jurnal Veteriner, 11(2), pp. 70-73.

Pusponegoro, A. D. (2005) Luka Dalam Buku Ajar IImu Bedah Edisi ke-2. Jakarta: EGC.

Sjamsuhidajat, R. and Jong, W. . (2005) Buku Ajar IImu Bedah, Edisi 2. Jakarta: Buku Kedokteran EGC.

Ulfa, N. K. et al. (2016) 'Identifikasi Metabolit Sekunder, Uji Toksisitas Dan Uji Aktivitas Antioksidan Ekstrak Daun Gamal (Gliricidia sepium)', in Mulawarman Pharmaceutical Conferences IV. Kalimantan Timur, pp. 232240.

Yogi, P. (2018) Uji Efektivitas Ekstrak Daun Gamal (Gliricidia maculata) sebagai Biofungisida terhadap Cendawan Patogen Colletotrichum capsici, Fusarium oxysporum dan Cercospora capsici Penyebab Penyakit pada Tanaman Cabai Merah (Capsicum annum L.) Secara In Vitro. Medan.

Yudaniayanti, I. S. (2005) 'Aktifitas Alkaline Phosphatase pada Proses Kesembuhan Patah Tulang Femur dengan Terapi $\mathrm{CaCO} 3$ Dosis Tinggi pada Tikus Jantan ( Sprague Dawley)', Media Kedokteran Hewan, 21(1), pp. 15-18. 